\title{
A Content Analysis of the Studies on the Use of Flipped Classrooms in Foreign Language Education
}

\author{
Sevil Filiz ${ }^{1, *} \&$ Aycan Benzet ${ }^{1}$ \\ ${ }^{1}$ Department of Curriculum and Instruction, Gazi University, Ankara, Turkey \\ "Correspondence: Department of Curriculum and Instruction, Gazi University, Ankara, Turkey. Tel: \\ 90-505-934-44-50. E-mail: sevilb@gazi.edu.tr
}

Received: May 13, 2018

Accepted: June 23, $2018 \quad$ Online Published: August 6, 2018

doi:10.5430/wje.v8n4p72

URL: https://doi.org/10.5430/wje.v8n4p72

\begin{abstract}
Teaching foreign languages via flipped classrooms, in which the typical elements of a course are reversed, has been a popular pedagogy recently as the modern digital technology is flourishing unprecedentedly. The aim of this study is to review a selected sample of 50 studies on flipped classroom instruction in foreign language education published from 2014 to 2018 in Turkey and abroad. A content analysis was conducted for each study in terms of study years, study types, study locations, foreign languages taught, language skills taught, research methods, sampling, data tools, data analysis procedure and variables through a 'Research Classification Form'. Results showed that studies were done mostly as articles in 2016 in 14 countries mostly in Turkey using quantitative research designs commonly. In these studies, flipped classroom instruction was implemented for teaching all skills of English as a foreign language. Samples generally consisted of higher education students with lower than 50 as a sample size. In these studies, as quantitative data collection tools, achievement tests were utilized and as for analysis procedures, mean and standard deviation were used predominantly. Additionally, the variables of Attitudes towards Foreign Language Lessons, Academic Performance, Perceptions, and Writing Performance were frequently researched. The findings obtained from this study are expected to contribute to future studies conducted on flipped classrooms in foreign language teaching.
\end{abstract}

Keywords: flipped classroom, flipped learning, inverted classroom, foreign/second language teaching, content analysis

\section{Introduction}

As the internet is widely used in all aspects of life, the informational technologies have been flourishing faster than ever to meet the needs of consumers and new appealing applications have been arising. Thus, technology has started to become an integral part of the new generation and it use in every field of education has become inevitable. Educational applications have been used widely and effectively by foreign language teachers, as well. In the past, only language laboratories used to be available for language teaching, now they are replaced by multimedia activities (Buyukaslan 2007, 2). Mehring (2016) stated that the adaptation of technology into English as a foreign language (EFL) classroom enabled a shift from a teacher-centered instruction environment to a more learner-centered, communicative-based one. This new learner-centered model forgoes unnecessary teacher-talk time during class by scaffolding learning from pre-class assignments, and expanding or deepening learning in class. This stance towards learning in which technology is used to reverse the traditional role of classroom time is sometimes referred to as the inverted or flipped classroom.

The flipped classroom method was suggested by teachers of chemistry D. Bergmann and A. Sams in 2007. They decided to record their slideshow lectures using screen capture soft-ware (instead of recording themselves giving the lecture) and started presenting their flipped model throughout the US (Correa, 2015). They soon discovered that more flexibility in class and more interaction not only between the teacher and students but also among the students were achieved by doing so. They clearly saw the benefits of a Flipped approach and wanted to share this teaching model with other educators. These two chemistry teachers started delivering seminars and workshops and in 2012 they published their first book entitled "Flip Your Classroom: Reach Every Student in Every Class Every Day" 
(Warden, 2016). ). In addition, they established the Flipped Learning Network (FLN) with the aim to 'provide educators with the knowledge, skills and resources to successfully implement Flipped Learning' (FLN, 2014).

Bergmann and Sams (2012) defined the flipped classroom as a concept where the workload shifts from in-class to homework and vice versa. That is, the activities traditionally done during class are done at home instead. Accordingly, the activities traditionally assigned as homework are done together with peers and the teacher as an in-class activity.

While often defined simply as school work at home and home work at school, flipped learning was described by FLN (2014) as,

"............ is a pedagogical approach in which direct instruction moves from the group learning space to the individual learning space, and the resulting group space is transformed into a dynamic interactive learning environment where the educator guides students as they apply concepts and engage creatively in the subject matter."

By FLN (2014) standards, for a class to be considered "flipped" it must have four basic pillars (Figure 1): (1) a flexible environment in which students choose when and where they learn, (2) a learning culture where student-centered model is applied, (3) an intentional content used by educators to maximize classroom time in order to adopt methods of student-centered, active learning strategies, depending on grade level and subject matter and (4) a professional educator who takes on less visibly prominent roles in a flipped classroom and remains as the essential ingredient that enables flipped learning to occur.

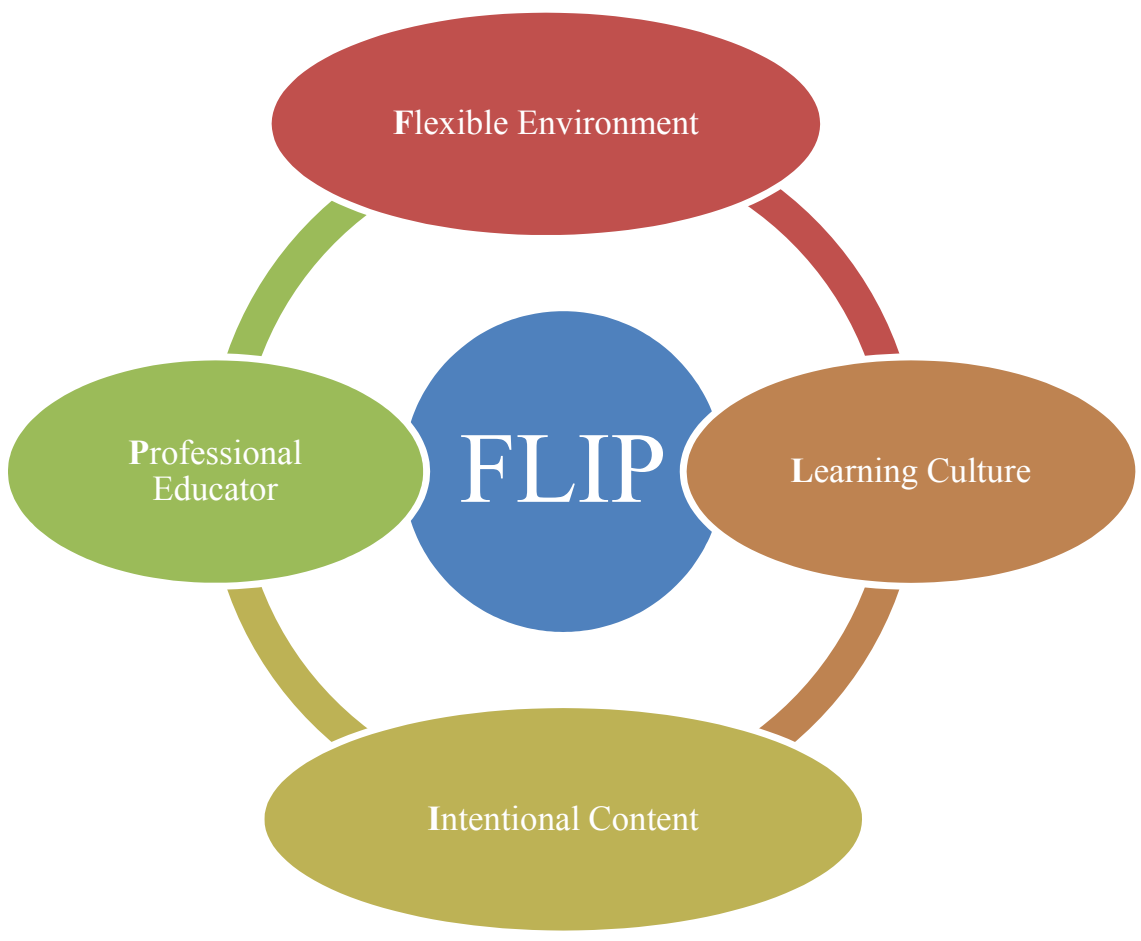

Figure 1. The Four Pillars of the Flipped Learning (FLN, 2014)

Temizyurek and Unlu (2015) summarized the procedure of the flipped classroom model. It has two components, outside-class and in-class. Outside-class component involves watching videos and doing quizzes, or mini tests that the teacher prepares before coming to classroom. Another outside-classroom component is using learning management systems such as online discussion groups which create a preview to in-class discussions. In-class component involves in-class discussions in small groups or as a whole class. Students' outside-class learning can be reinforced with in-class activities that involve critical thinking and problem solving activities. We provided a figure summarizing the main points of the study by Temizyurek and Unlu (2015). 

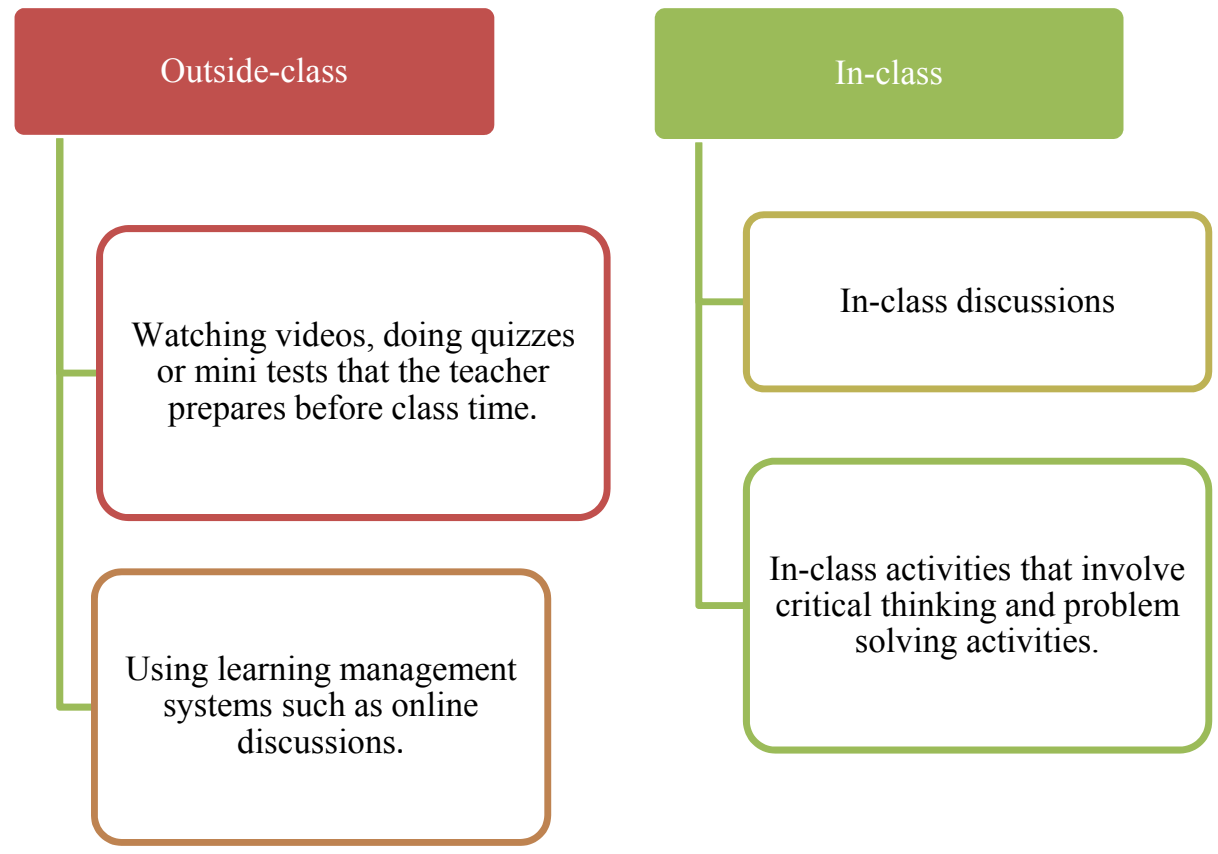

Figure 2. The Procedure of the Flipped Classroom Model.

The flipped classroom concept has the following advantages: Students can review material at their own pace and according to their own needs; the videos make the most of class time to advance the deeper, inquiry-based learning; teachers can structure class time to optimize individualized attention to students; students have the opportunity to make use of the material they are learning in a reinforced setting; it fosters autonomous learning and student-student/student-teacher interaction; it enables educators to use the language of today's students who use the web and social media for information and interaction frequently; it provides transparency of instruction and parent/tutor involvement; it develops higher order skills in the classroom; it allows the teacher to improve skills in which the student has not been proficient yet; it provides students with real life situations, students can have a chance to listen to both native speakers and their teachers; teachers are advantageous as there is ready-to-use rich content; language educators are often able to repurpose time to incorporate activities that did not previously fit within the time constraints of the curriculum( Flipping the classroom, 2011; Bergmann \& Sams, 2012; Brame, 2013; Herreid \& Schiller, 2013; Muldrow,2013; Basal, 2015; Correa, 2015; Chilingaryan \& Zvereva, 2016; Demirel, 2016; Quda \& Ahmed, 2016).

It was emphasized that the flipped classroom uses modern technology to mirror the success of many introductory humanities courses which generally achieve much higher attendance than introductory STEM courses (Leitch, 2015). In a humanities class, students receive initial exposure to content at home through reading both primary and secondary sources and apply their understanding of that content through active, learner-centered class activities. The flipped classroom adapts this model for skills-based classes by exposing students to content through online video lectures, then applying cooperative, active learning strategies in class to help students master and apply content. In the light of this fact, the flipped classroom seems to be very relevant to the foreign language classrooms which benefit from student-centered, discovery-learning and collaborative environment. Moreover, Warden (2016) suggested that the benefit of adopting a flipped classroom approach in foreign language classroom would clearly come from assigning pre-class tasks thereby creating more time in class which could be dedicated to practicing the language in meaningful communicative activities. According to Temizyurek and Unlu (2015), if the grammar is taught outside the classroom, the classroom time can be used to perform communicative and language use activities in line with communicative approach.

An increase in the popularity of flipped learning studies has been seen in recent years (Abeysekera \& Dawson, 2015; Lo, Lie, \& Hew, 2018; Tseng, Lin, \& Chen, 2018). Yarbro, Arfstrom, McKnight and McKnight (2014)'s summary of recent research on flipped learning showed how widely flipped learning has become embedded in most disciplines, including foreign languages, and widely used in higher education. However, as a result of literature review, it has 
been noticed that the content analysis conducted for the studies about the flipped classroom model was scarce. First, O'Flahert and Phillips (2015) aimed to provide a comprehensive overview of the relevant research in their scoping review of the flipped classroom in higher education and analyzed 28 studies. Secondly, Zainuddin and Halili (2016) analyzed the trends and contents of flipped classroom research based on 20 articles that report on flipped learning classroom initiatives between 2013 and 2015. Thirdly, Aydin and Demirer (2017) conducted a content analysis for 90 studies on flipped model carried out between 2011 and 2015 and analyzed under seven different categories that are theoretical dimension, sampling, discipline, research method, tools used in the implementation process, variables, and pedagogical outcomes. Fourthly, Yildiz, Sarsar and Çobanoğlu (2017) reviewed the literature of flipped classroom practices in 40 studies during 2011-2016 from Turkey and abroad. They examined the studies in terms of definitions, research methodologies and results. Lastly, Sakar and Sagir (2017) analyzed 61 studies on flipped classroom model in science courses. In the literature review, to the best of our knowledge, there are no studies regarding the content analysis conducted on the flipped classrooms in foreign language education research. We think that the current study will have a great contribution to fill this important gap and facilitate the identification of the unexplored scopes of the flipped classroom method in foreign language education research; thus, pave the way of future research.

In this context, the aim of this study is to provide a panoramic overview of the flipped classroom concept in foreign language education research from 2014 to 2018 by identifying the trends and patterns through a systematic review of the related literature. Within this perspective, this study seeks to answer the following questions about the studies focusing on flipped classroom implementations in foreign language education between 2014 and 2018 in Turkey and abroad:

1. What is the distribution of the studies in terms of years (2014-2018)?

2. What is the type (article or thesis) distribution of the studies in terms of years?

3. What is the distribution of the studies in terms of location?

4. For which language teaching was the flipped classroom implemented in the studies?

5. For which language skill was the flipped classroom implemented in the studies?

6. What research methods were employed in the studies?

7. Which sample groups and sample sizes were used in the studies?

8. What data collection tools were utilized in the studies?

9. What type of data analysis procedures were employed in the studies?

10. What dependent variables were used in the studies?

\section{Methods}

\subsection{Research Design}

This study was conducted using content analysis to analyze 50 studies on flipped classroom instruction in foreign language education published from 2014 to 2018. Content analysis, which is an organized interpretation of such concepts and themes that help readers to understand better, brings the similar data together under specific concepts and themes (Yildirim \& Simsek, 2006). Besides, it is a systematic and renewable technique that summarizes the words of a text into smaller content categories with respect to codes based on specific rules (Buyukozturk, Cakmak, Akgun, Karadeniz, \& Demirel, 2009). The rationale for using content analysis in this study is that its use may link the data which are related to each other and analyze the themes that can be read by readers conveniently and efficiently, it may also be used by researchers as a reference for potential future research (Bauer, 2000).

\subsection{Data Collection Tool}

Each paper was subjected to a content analysis using the "Research Classification Form (RCF). RCF is a modified version of the "Paper Classification Form (PCF)," which was developed by Sozbilir, Kutu and Yasar, 2012. The form is composed of ten components which provide descriptive information for the identification of the research, subject (title) of the paper, methods employed in the study, sampling and sample sizes, data collection tools used, data analysis methods and variables.

\subsection{Sample}

The present study investigates 50 different studies on flipped classroom instruction in foreign language education 
published from 2014 to 2018 . The 50 studies in this context were accessed and found through electronic databases such as ProQuest thesis database, Turkey Thesis Catalog, Science Direct (http://www.sciencedirect.com/), Tailor \& Francis Online (http://www.tandfonline.com/), Google Academic search engine, TUBITAK ULAKBIM DergiPark, and EBSCOhost-ERICdatabases. These studies, involving 21 theses and 29 articles, were published between 2014 and 2018 (see Appendix A-B for the studies). In order to find the relevant articles and theses, "Flipped classroom", "Flipped learning", "Inverted learning", "Inverted classroom" and "Second-Foreign Language Teaching-Education" key words were searched. The search was done in Turkish and in English.

\subsection{Data Analysis}

By means of research information form, each study was reviewed in terms of content and the data were transferred to Microsoft Excel. The results were descriptively analyzed and shown in frequency and percentage tables to interpret the themes and obtain the most frequently employed categories in flipped foreign language classroom research. Content analysis brings similar themes and concepts together and interprets in an understandable way.

\section{Findings}

This section presents findings related to the 50 studies on flipped foreign language classrooms in 10 sub-categories.

\subsection{The Distribution of the Studies in Terms of Years}

The frequency distribution of the studies between 2014 and 2018 was shown in Table1.

Table 1. Frequency Distribution of the Studies between 2014 and 2018

\begin{tabular}{|c|c|c|c|c|}
\hline \multirow[b]{2}{*}{ Years } & \multicolumn{4}{|c|}{ Studies } \\
\hline & \multicolumn{2}{|c|}{ Articles Theses } & $\mathbf{N}$ & $\%$ \\
\hline 2014 & 2 & 3 & 5 & 10.0 \\
\hline 2015 & 5 & 3 & 8 & 16.0 \\
\hline 2016 & 11 & 7 & 18 & 36.0 \\
\hline 2017 & 8 & 7 & 15 & 30.0 \\
\hline 2018 & 3 & 1 & 4 & 8.0 \\
\hline Total & 29 & 21 & 50 & 100 \\
\hline
\end{tabular}

There has been an increase in the studies since 2016 in which the most studies were carried out (36\%). As we are in the first half of 2018, probably there will be more studies this year.

\subsection{The Distribution of the Studies between 2014 and 2018 in Terms of Their Type}

Table 2. Frequency Distribution of the Studies in Terms of Their Types (Article or Thesis)

\begin{tabular}{lll}
\hline Study Type & N & \% \\
\hline Article & 29 & 58.0 \\
Thesis & 21 & 42.0 \\
Total & $\mathbf{5 0}$ & $\mathbf{1 0 0}$ \\
\hline
\end{tabular}

The frequency distribution of the studies between 2014 and 2018 in terms of their types (article or thesis) was shown in Table 2. As can be seen, the number of the articles (58\%) conducted in the field of flipped classroom instruction in foreign language education is higher than the number of theses $(42 \%)$.

\subsection{The Distribution of the Studies in Terms of Location}

As seen in Table 3, Turkey (34\%) is the country where the most studies on the flipped classroom instruction in foreign language education were conducted. It is followed by the USA (18\%), Taiwan (12\%), Iran (6\%), Saudi Arabia (6\%), China (4\%), Japan (4\%), United Arab Emirates (4\%), Egypt (2\%), England (2\%), Indonesia (2\%), Korea (2\%), Russia (2\%) and Thailand (2\%), respectively. 
Table 3. Frequency Distribution of the Studies in Terms of Location

\begin{tabular}{|c|c|c|c|c|}
\hline University & $\mathbf{N}$ & Country & $\mathbf{N}$ & $\%$ \\
\hline Hohai University & 1 & China & 2 & 4.0 \\
\hline Shanghai Jiao Tong University & 1 & & & \\
\hline The British University in Egypt & 1 & Egypt & 1 & 2.0 \\
\hline The University of Chichester & 1 & England & 1 & 2.0 \\
\hline Islamic Azad University & 1 & Iran & 3 & 6.0 \\
\hline Kar Higher Education Institute & 1 & & & \\
\hline University of Isfahan & 1 & & & \\
\hline Universitas Negeri Malang & 1 & Indonesia & 1 & 2.0 \\
\hline Miyagi University of Education & 1 & Japan & 2 & 4.0 \\
\hline Tokyo University of Technology & 1 & & & \\
\hline Chung-Ang University & 1 & Korea & 1 & 2.0 \\
\hline National Research Tomsk Polytechnic University & 1 & Russia & 1 & 2.0 \\
\hline King Saud University & 1 & Saudi Arabia & 3 & 6.0 \\
\hline Qassim University & 1 & & & \\
\hline Taif University & 1 & & & \\
\hline Asia University & 1 & Taiwan & 6 & 12.0 \\
\hline National Central University & 2 & & & \\
\hline National Kaohsiung First University of Sci. and Tech. & 2 & & & \\
\hline National Taiwan Normal University & 1 & & & \\
\hline Thepsatri Rajabhat University & 1 & Thailand & 1 & 2.0 \\
\hline Afyon Kocatepe University & 1 & Turkey & 17 & 34.0 \\
\hline Anadolu University & 1 & & & \\
\hline Boğaziçi University & 1 & & & \\
\hline Bülent Ecevit University & 1 & & & \\
\hline Çağ University & 1 & & & \\
\hline Gazi University & 4 & & & \\
\hline Gaziantep University & 1 & & & \\
\hline Mef University & 2 & & & \\
\hline Mersin University & 1 & & & \\
\hline Muğla Sıtkı Koçman University & 2 & & & \\
\hline Süleyman Demirel University & 1 & & & \\
\hline Yıldız Teknik University & 1 & & & \\
\hline The British University in Dubai & 1 & United Arab Emirates & 2 & 4.0 \\
\hline Zayed University & 1 & & & \\
\hline Baylor University & 1 & & 9 & 18.0 \\
\hline Hofstra University & 1 & & & \\
\hline Pepperdine University & 1 & USA & & \\
\hline San Diego State University & 1 & & & \\
\hline The University of Iowa & 1 & & & \\
\hline The University of Virginia & 1 & & & \\
\hline The University of Pennsylvania & 2 & & & \\
\hline Washington State University & 1 & & & \\
\hline Total & & & 50 & 100 \\
\hline
\end{tabular}




\subsection{The Distribution of the Flipped Instruction Studies in Terms of Foreign Languages Taught}

Table 4. Frequency Distribution of the Flipped Instruction Studies in Terms of Foreign Languages Taught

\begin{tabular}{lll}
\hline Foreign Languages Taught & $\mathbf{N}$ & $\mathbf{\%}$ \\
\hline Chinese & 4 & 8.0 \\
English & 38 & 76.0 \\
French & 1 & 2.0 \\
Italian & 1 & 2.0 \\
Japanese & 1 & 2.0 \\
Spanish & 5 & 10.0 \\
Total & $\mathbf{5 0}$ & $\mathbf{1 0 0}$ \\
\hline
\end{tabular}

As for the data presented in Table 4, the flipped classroom instruction was implemented for teaching English (76\%) as a foreign language in most of the studies. English was followed by Spanish (10\%) and Chinese (8\%) as a foreign language. Studies on the flipped classroom instruction were also done for teaching French (2\%), Italian (2\%) and Japanese $(2 \%)$ as a foreign language.

3.5 The Distribution of the Flipped Instruction Studies in Terms of Language Skills Taught

Table 5: Frequency distribution of the Flipped Instruction studies in terms of Language Skills Taught

\begin{tabular}{lll}
\hline Language Skills Taught & $\mathbf{N}$ & $\mathbf{\%}$ \\
\hline Reading & 2 & 4.0 \\
Listening & 2 & 4.0 \\
Speaking & 6 & 12.0 \\
Writing & 10 & 20.0 \\
Grammar & 7 & 14.0 \\
All skills & 23 & 46.0 \\
Total & $\mathbf{5 0}$ & $\mathbf{1 0 0}$ \\
\hline
\end{tabular}

In most of the studies, all language skills (46\%) were taught with the implementation of the flipped classroom instruction simultaneously (Table 5); however, the flipped instruction was generally implemented in writing classrooms (20\%). It was followed by grammar (14\%) and speaking (12\%) classrooms.

3.6 The Distribution of the Research Methods Employed in the Studies

Table 6. Frequency Distribution of the Research Methods

\begin{tabular}{llcll}
\hline Research Methods & Studies & Theses & N & \% \\
\hline Quantitative & Articles & 9 & 25 & 50.0 \\
Qualitative & 16 & 3 & 6 & 12.0 \\
Mixed & 3 & 9 & 19 & 38.0 \\
Total & 10 & $\mathbf{2 1}$ & $\mathbf{5 0}$ & $\mathbf{1 0 0}$ \\
\hline
\end{tabular}

The research methods of the studies on the flipped classroom instruction in foreign language education were displayed in Table 6. As far as the data concerned in Table 6, the quantitative research approach (50\%) was employed most often in the studies, which was followed by the combined use of qualitative and quantitative research approaches (mixed method) (38\%) in the studies. On the other hand, the qualitative research approach (12\%) was found to be used less frequently. 


\subsection{The Distribution of the Sample Groups and Sample Sizes Employed in the Studies}

Table 7. Frequency Distribution of the Sample Groups

\begin{tabular}{lll}
\hline Sample Groups & N & $\mathbf{\%}$ \\
\hline Primary School Students & - & - \\
Secondary School Students & 9 & 18.0 \\
Students at Higher Education & 41 & 82.0 \\
Total & $\mathbf{5 0}$ & $\mathbf{1 0 0}$ \\
\hline
\end{tabular}

Table 8. Frequency Distribution of the Sample Sizes

\begin{tabular}{lll}
\hline Sample Sizes & N & \% \\
\hline$<50$ & 32 & 64.0 \\
$51-100$ & 12 & 24.0 \\
$100<$ & 6 & 12.0 \\
Total & $\mathbf{5 0}$ & $\mathbf{1 0 0}$ \\
\hline
\end{tabular}

As can be seen in Table 7, researchers mostly studied with students at higher education (82\%). This finding also indicates that researchers have never studied with primary school students. As for the sample size, the majority of the samples consisted of less than 50 participants (64\%) (Table 8). Nevertheless, the researchers did not carry out studies including more than 100 participants frequently (12\%). While the lowest group size was 10 (Rubi, 2017), the highest group size was 419 (Mckeown, 2016).

3.8 The Distribution of the Data Collection Tools Employed in the Studies

Table 9. Frequency Distribution of the Data Collection Tools

\begin{tabular}{ll}
\hline Data Collection Tools & $\mathbf{N}$ \\
\hline Interview & 24 \\
Achievement Tests & 33 \\
Attitude Tests & 4 \\
Questionnaires & 28 \\
Documents & 1 \\
Observation & 6 \\
Logs & 5 \\
Journals & 6 \\
Other & 6 \\
Total & 17 \\
\hline
\end{tabular}

As seen in Table 9, the frequency values show that the data of the studies were very often collected by means of achievement tests $(\mathrm{N}=33)$. This was followed by questionnaires $(\mathrm{N}=28)$, interviews $(\mathrm{N}=24)$, and other tools $(\mathrm{N}=17)$. In addition, some studies also collected data using journals $(\mathrm{N}=6)$, observation $(\mathrm{N}=6), \operatorname{logs}(\mathrm{N}=5)$, attitude tests $(\mathrm{N}=4)$ and documents $(\mathrm{N}=1)$. Since more than one data collection tool may have been used in a study, percentage values were not calculated. 
3.9 The Distribution of the Data Analysis Procedures Employed in the Studies

Table 10. Frequency Distribution of the Analyses

\begin{tabular}{|c|c|c|c|}
\hline & & & $\mathbf{N}$ \\
\hline \multirow{11}{*}{ Quantitative Data Analysis } & \multirow[t]{3}{*}{ Descriptive } & Frequency/Percentage & 9 \\
\hline & & Mean/Standard Deviation & 30 \\
\hline & & Graphic Display & - \\
\hline & \multirow[t]{8}{*}{ Inferential } & T-test & 28 \\
\hline & & Correlation & 5 \\
\hline & & ANOVA-ANCOVA & 10 \\
\hline & & MANOVA/MANCOVA & 1 \\
\hline & & Factor Analysis & 1 \\
\hline & & Regression & 2 \\
\hline & & Chi-Square & - \\
\hline & & Non-parametric Tests & 5 \\
\hline \multirow{5}{*}{ Qualitative Data Analysis } & \multirow[t]{3}{*}{ Subtotal } & & 91 \\
\hline & & Content Analysis & 20 \\
\hline & & Qualitative Descriptive Analysis & 16 \\
\hline & Subtotal & & 36 \\
\hline & Total & & 127 \\
\hline
\end{tabular}

Given the data analysis techniques, the majority of the studies $(\mathrm{N}=91)$ used quantitative data analysis, while 36 studies; on the other hand, utilized qualitative analysis procedures. To be more specific, mean and standard deviation $(\mathrm{N}=30)$ were the most common descriptive analysis procedures. Regarding inferential analysis, the use of t-test $(\mathrm{N}=28)$ appeared to be most common procedure; however, the number of more sophisticated analysis procedures such as MANOVA/MANCOVA, factor analysis and regression were quite low.

As for the qualitative analysis types, content analyses $(\mathrm{N}=20)$ was found to be used more often compared to descriptive qualitative analyses $(\mathrm{N}=16)$. Since more than one data analysis type may have been used in a study, percentage values were not calculated.

\subsection{The Distribution of Dependent Variables Employed in the Studies}

Table 11. Frequency Distribution of the Dependent Variables

\begin{tabular}{lll}
\hline Dependent Variables & $\mathbf{N}$ & $\mathbf{\%}$ \\
\hline Academic Performance & 11 & 12.2 \\
Satisfaction with the model & 6 & 7.0 \\
Perceptions & 10 & 11.1 \\
Interpersonal-Interpretive Performance & 1 & 1.1 \\
Effectiveness & 2 & 2.2 \\
Feasibility & 1 & 1.1 \\
Attitudes towards foreign language lessons & 17 & 18.8 \\
Active Learning & 2 & 2.2 \\
Collaboration & 1 & 1.1 \\
Interaction & 6 & 7.0 \\
Writing Performance & 9 & 10 \\
Grammatical knowledge & 6 & 7.0 \\
Lexical knowledge & 1 & 1.1 \\
Student-Learner Autonomy & 2 & 2.2 \\
Language Classroom Anxiety & 1 & 1.1 \\
Reading Anxiety & 1 & 1.1 \\
Self-Directed Learning Readiness & 2 & 2.2 \\
Speaking Skills & 7 & 7.7 \\
Retention of Knowledge in EFL context & 1 & 1.1 \\
Reading comprehension ability & 1 & 1.1 \\
Out of class time investment & 1 & 1.1 \\
Higher -order thinking skills & 1 & 1.1 \\
Total & $\mathbf{9 0}$ & $\mathbf{1 0 0}$ \\
\hline
\end{tabular}


In the studies, the effects of the flipped foreign language instruction on different variables were usually investigated. Thus, the independent variables were usually flipped learning, flipped instruction, flipped classroom or inverted classroom. The dependent variables of the studies on the flipped classroom instruction in foreign language education were displayed in Table 11. Researchers frequently preferred to study the concepts of "Attitudes towards foreign language lessons" (18.8\%), "Academic Performance" (12.2\%), "Perceptions" (11.1\%) and "Writing Performance" $(10 \%)$, as dependent variables (Table 11). According to the analysis of the effects on dependent variables, it was found that flipped foreign language implementation had positive effects on all the dependent variables except one dependent variable, leaner autonomy.

\section{Discussion and Future Implications}

This study aims to provide a panoramic overview of flipped classroom in foreign language research from 2014 to 2018 identifying trends and patterns through a content analysis of 50 studies. The research data was analyzed under 10 sub-categories which are study years, study types, study locations, foreign languages taught, language skills taught, research methods, sampling, tools used in the implementation process, data analysis procedure and variables.

First of all, according to the distribution of the studies in terms of years, an increase in the studies after 2015 was seen, with the highest number in 2016 (36\%). Similar results are seen in the studies conducting content analysis on the flipped classroom model (e.g. Aydin \& Demirer, 2017; Sagir \& Sakar, 2017). Bergmann and Sams, who are the pioneers of the flipped classroom movement, introduced the method in 2012 after successfully flipping their classes. In addition, Muldrow (2013) stated that the popularity of the flipped classroom has grown rapidly in recent years, due in part to the understanding that traditional methods of instruction are not always the most successful. This result shows that the researchers in foreign language education have begun to be more interested in the flipped model since 2016.

Secondly, in terms of the types of the studies, it was found that the number of the articles (58\%) conducted in the field of flipped classroom instruction in foreign language education is higher than the number of the theses (42\%). Likewise, in other similar studies, the number of articles is much more than the number of theses (e.g. Aydin \& Demirer, 2017; Sagir \& Sakar, 2017).

Thirdly, in terms of the locations of the studies on flipped classroom instruction in foreign language education, this content analysis identified 50 studies from 14 countries, which are Turkey (34\%), the USA (18\%), Taiwan (12\%), Iran (6\%), Saudi Arabia (6\%), China (4\%), Japan (4\%), United Arab Emirates (4\%), Egypt (2\%), England (2\%), Indonesia (2\%), Korea (2\%), Russia (2\%) and Thailand (2\%), respectively. We discovered that there is a notable absence of literature from Europe, which can be resulted from the fact that there may be related studies in languages other than English; therefore, we could not include these studies in our review.

Fourthly, this study reported that flipped classroom instruction was implemented for teaching English (76\%) as a foreign language in the most studies. This high rate is very normal because teaching English as a foreign or second language is a common research field worldwide. It was also found that studies on the flipped classroom instruction were also done in teaching Spanish (10\%), Chinese (8\%), French (2\%), Italian (2\%) and Japanese (2\%) as a foreign language. This shows that if the flipped model does work in teaching English as a foreign language, it will directly be beneficial for all the learners of any language around the world (Wang, An \& Wright, 2017), so there should be more future research regarding the use of this concept in teaching other languages as a foreign language.

Another finding is about the language skills taught with the implementation of the flipped classroom instruction. In most of the studies all language skills (46\%) were taught, but generally, flipped instruction was implemented in the writing classrooms $(20 \%)$ followed by the grammar (14\%) and speaking (12\%) classrooms. Further research may be conducted for the investigation of the efficacy of flipped learning in improving different foreign language skills such as reading and listening.

Regarding the research methods, quantitative studies $(50 \%)$ were found to be dominant in the studies about the flipped classroom instruction in foreign language education, which was followed by mixed method (38\%) and the qualitative studies (12\%). This common preference towards quantitative methods can be because the research topic is related to the implementation of flipped classrooms. This tendency is not consistent with other content analysis studies. In both Zainuddin and Halili (2016) and Aydin and Demirer's (2017) studies, the most frequently used methodologies in flipped classroom research were the mixed-method approach (quantitative and qualitative), followed by the quantitative approach.

Our findings revealed that researchers generally studied with students at higher education (82\%) in line with the 
previous research about flipped classroom models (e.g. Zainuddin \& Halili, 2016; Aydin \& Demirer, 2017; Sakar \& Sagir, 2017; Yildiz et al., 2017). This can be explained both by the sample accessibility of the researchers and by the availability of the technology for the students at higher education. O'Flaherty and Phillips (2015) stated that blended learning has become increasingly popular in higher education globally, forming the cornerstone of curriculum design and providing opportunity for learning. However, our findings showed that researchers never studied with primary school students. Given that foreign language education starts at an early age, it is important to study whether this flipped classroom model in foreign language education is appropriate for younger students or not. Therefore, further research maybe conducted for the investigation of the efficacy of flipped learning for primary school students. As for the sample size of the studies, it was found that the researchers mostly worked with less than 50 participants $(64 \%)$. Since most of the studies are quantitative, working with small number of participants may be easier for the researchers.

Additionally, in terms of data collection tools, it was found that the researchers often used quantitative data collection tools such as achievement tests $(\mathrm{N}=33)$ and questionnaires $(\mathrm{N}=28)$. The tools such as journals $(\mathrm{N}=6)$, observation $(\mathrm{N}=6), \operatorname{logs}(\mathrm{N}=5)$, attitude tests $(\mathrm{N}=4)$ and documents $(\mathrm{N}=1)$ appeared to be less frequent to collect data. This may be due to the scarcity of the qualitative research. Another finding is that the researchers utilized multiple instruments to collect rich information and identify effective flipped learning practices (e.g. Zainuddin \& Halili, 2016). As widely known, the use of more than a single data collection tool is strongly recommended to enhance validity and reliability.

As for the data analysis techniques, our findings shows that the majority of studies $(\mathrm{N}=91)$ employed quantitative data analysis, while some of them $(\mathrm{N}=36)$ used qualitative analysis procedures. This preference is related to the research methods of the studies. For quantitative analysis, the studies were analyzed by mean and standard deviation $(\mathrm{N}=30)$ and $\mathrm{t}$-test $(\mathrm{N}=28)$. The number of more sophisticated analysis procedures such as MANOVA/MANCOVA, factor analysis and regression were quite low in inferential analysis group. Among the qualitative analysis types, content analyses $(\mathrm{N}=20)$ was used more often compared to descriptive qualitative analyses $(\mathrm{N}=16)$. Moreover, we also found that the data analysis techniques of the studies had not been analyzed in former research (e.g. Zainuddin \& Halili, 2016; Aydin \& Demirer, 2017; Sakar \& Sagir, 2017; Yildiz et al., 2017).

Lastly, for the dependent variables of the studies about the flipped classroom instruction in foreign language education, we found that researchers frequently preferred to study the concepts of "Attitudes towards foreign language lessons" (18.8\%), "Academic Performance" (12.2\%), "Perceptions" (11.1\%) and "Writing Performance" $(10 \%)$, as dependent variables. This finding is again consistent with the former research (Aydin \& Demirer, 2017; Sagir \& Sakar, 2017). On the other hand, we revealed that some dependent variables such as reading anxiety, higher-order thinking skills, lexical knowledge, were rarely studied. According to the analysis of the effects on dependent variables, it was detected that flipped foreign language implementation had positive effects on all the dependent variables except one dependent variable, which is leaner autonomy. Edis (2017) found that flipped instruction for English language learners has no effect on learner autonomy in her research. We recommend that future flipped classroom studies in foreign language teaching may investigate different and less studied variables such as reading anxiety and higher-order thinking skills.

\section{Conclusion}

Consequently, we can state that the studies on flipped classrooms in foreign language education have been increasing in line with the integration of technology into education. We aim to identify the trends in this research area through a content analysis of 50 studies between 2014 and 2018 from Turkey and abroad. The findings about study years, study types, study locations, foreign languages taught, and language skills taught, research methods, sampling, tools used in the implementation process, data analysis procedure and variables were discussed based on the results of this study. We expect these findings to contribute to the studies conducted on flipped classroom models in foreign language education. Thus, this study is thought to promote the identification of gaps in the research area and support future studies.

\section{References}

Abeysekera, L., \& Dawson, P. (2015). Motivation and cognitive load in the flipped classroom: Definition, rationale and a call for research. Higher Education Research and Development, 34(1), 1-14. https://doi.org/10.1080/07294360.2014.934336

Aydin, B., \& Demirer, V. (2017). A Comprehensive Analysis of the Studies Conducted in the Framework of Flipped 
Classroom Model. Eğitim Teknolojisi Kuram ve Uygulama, 7(1), 57-82.

Basal, A. (2015). The implementation of a flipped classroom in foreign language teaching. Turkish Online Journal of Distance Education, 16(4), 28-37.

Bauer, M. W. (2000). Classical content analysis: A review. In M. W. Bauer \& G. Gaskell (Eds.), Qualitative researching with text, image and sounds (pp. 131-151). London, UK: Sage. https://doi.org/10.4135/9781849209731.n8

Bergmann, J., \& Sams, A. (2012). Flip Your Classroom: Talk To Every Student in Every Class Every Day. Washington, DC: ISTE. from https://www.liceopalmieri.gov.it/wp-content/uploads/2016/11/Flip-Your-Classroom.pdf

Brame, C.J. (2013). Flipping the classroom. Vanderbilt University Center for Teaching. Retrieved from: http:/cft.vanderbilt.edu/teaching-guides/teaching-activities/flipping-the-classroom/

Buyukaslan, A. (2007, May). Yabancı dil Türkçenin öğretilmesinde yeni yöntemler, bilişim uygulamaları, çözüm önerileri, I. Uluslar arası Bilgisayar ve Öğretim Teknolojileri Sempozyumu, Çanakkale Onsekiz Mart Üniversitesi Eğitim Fakültesi, Çanakkale.

Buyukozturk, Ş., Çakmak, E. K., Akgün, Ö. E., Karadeniz, Ş., \& Demirel, F. (2009). Bilimsel araştırma yöntemleri (5. bs.). Ankara: PegemA Yayıncilık.

Chilingaryan, K., \& Zvereva, E. (2016). Methodology of Flipped Classroom as a Learning Technology in Foreign Language Teaching. 7th International Conference on Intercultural Education "Education, Health and ICT for a Transcultural World”, EDUHEM 2016, 15-17 June 2016, Almeria, Spain.

Correa, M. (2015). Flipping the Foreign Language Classroom and Critical Pedagogies: A (New) Old Trend. Higher Education for the Future, 2(2), 114-125. https://doi.org/10.1177/2347631115584122

Demirel, E. (2016). Basics and Key Principles of Flipped Learning: Classes Upside Down. International Journal of Languages, Literature and Linguistics, 2(3).

Flipped Learning Network board members. (2014) "What is Flipped Learning?" Flipped Learning Network, Retrieved from http://www.flippedlearning.org/ domain/46

Flipping the classroom: Hopes that the internet can improve teaching may at last be bearing fruit. (2011, September 17), The Economist, 9, 35-44.

Herreid, C.F., \& Schiller, N.A. (2013). Case studies and the flipped classroom. Journal of College Science Teaching, 42(5), 62-66.

Lo, C.K., Lie, C.W., \& Hew, K.F. (2018). Applying 'First Principles of Instruction' as a Design theory of the flipped classroom: Findings from a collective study of four secondary schoolsubjects. Computers \& Education, 118, 150-165. https://doi.org/10.1016/j.compedu.2017.12.003

Leitch, A. (2015). "Flipping the Latin Classroom". All Graduate Plan B and other Reports. (Unpublished Doctoral Thesis). Retrieved from https://digitalcommons.usu.edu/gradreports/532

Mehring, J. (2016). Present Research on the Flipped Classroom and Potential Tools for the EFL Classroom. Computers in the Schools, 33(1), 1-10. https://doi.org/10.1080/07380569.2016.1139912

Muldrow, K. (2013). A New Approach to Language Instruction Flipping the Classroom. The Language Educator.

O'Flaherty, J., \& Phillips, C. (2015). The use of flipped classrooms in higher education: A scoping review. The Internet and Higher Education, 25, 85-95. https://doi.org/10.1016/j.iheduc.2015.02.002

Quda, H., \& Ahmed, K. (2016). Flipped Learning As A New Educational Paradigm: An Analytical Critical Study. European Scientific Journal, 12(10). http://dx.doi.org/10.19044/esj.2016.v12n10p417

Sakar, D., \& Sagir, S. (2017). Flipped classroom model in education. International Journal of Social Sciences and Education Research, 3(5), 1904-1916.

Sozbilir, M., Kutu, H., \& Yasar, M.D. (2012). Science education research in Turkey: A Content analysis of selected features of papers published. In J. Dillon \& D. Jorde (eds.), The World of Science Education: Handbook of Research in Europe (pp. 1-35). Rotterdam: Sense publishers. https://doi.org/10.1007/978-94-6091-900-8_14

Temizyurek, F., \& Unlu, N.A. (2015). The Use of Technology in Language Teaching Material as an Example: "Flipped Classroom". Bartin University Journal of Faculty of Education, 4(1), 64-72. 
https://doi.org/10.14686/BUEFAD.2015111015

Tseng, M-F., Lin C-H., \& Chen, H. (2018). An immersive flipped classroom for learning Mandarin Chinese: design, Implementation, and outcomes. Computer Assisted Language Learning. https://doi.org/10.1080/09588221.2018.1440603

Wang, J., An, N., \&Wright, C. (2018). Enhancing beginner learners' oral proficiency in a flipped Chinese foreign language classroom. Computer Assisted Language Learning. https://doi.org/10.1080/09588221.2017.1417872

Warden, A. (2016). Investigating the use of a Flipped Approach to Grammar Input in an English as a Foreign Language Classroom, (Unpublished Doctoral Thesis) The University of Chichester.

Yarbro, J., Arfstrom, K. M., McKnight, K., \& McKnight, P. (2014). Extension of a review of flipped learning. Retrieved from http://flippedlearning.org/cms/lib07/VA01923112/Centricity/Domain/41/Extension\%20of\%20Flipped\%20Learn ing\%20Lit\%20Review\%20June\%202014.pdf

Yildirim, A., \& Simsek, H. (2006). Sosyal bilimlerde nitel araştırma yöntemleri (5. bs.). Ankara: Seçkin Yayıncılık.

Yildiz, S., Sarsar, F., \& Cobanoğlu, A. (2017). A Literature Review of Flipped Classroom Practices. Electronic Journal of Social Sciences, 16(60), 76-86.

Zainuddin, Z., \& Halili, S. H. (2016). Flipped Classroom Research and Trends from Different Fields of Study. International Review of Research in Open and Distributed Learning, 17(3), 313-340.

Appendix A. Lists of the Reviewed Articles about the Use of Flipped Classrooms in Foreign Language Education

Adnan, M. (2017). Perceptions of senior-year ELT students for flipped classroom: a materials development course. Computer Assisted Language Learning, 30(3-4), 204-222. https://doi.org/10.1080/09588221.2017.1301958

Afrilyasanti, R., Cahyona, B. Y., \& Astuti, U.B. (2016). Effect of Flipped Classroom Model on Indonesian EFL Students' Writing Ability Across and Individual Differences in Learning. International Journal of English Language and Linguistics Research, 4(5), 65-81.

Al-Harbi S. S., \& Alshumaimeri, Y. A. (2016). The Flipped Classroom Impact in Grammar Class on EFL Saudi Secondary School Students' Performances and Attitudes. English Language Teaching, 9(10), 60-80. https://doi.org/10.5539/elt.v9n10p60

Alsowat, H. (2016). An EFL Flipped Classroom Teaching Model: Effects on English Language Higher-order Thinking Skills, Student Engagement and Satisfaction. Journal of Education and Practice, 7(9), 108-121.

Amiryousefi, M. (2017). The incorporation of flipped learning into conventional classes to enhance EFL learners' L2 speaking, L2 listening, and engagement. Innovation in Language Learning and Teaching. https://doi.org/10.1080/17501229.2017.1394307

Basal, A. (2015). The implementation of a flipped classroom in foreign language teaching. Online Journal of Distance Education, 16(4), 28-37.

Chen, S., She, J., Kameda, H., \& Ohno, S. (2014). Implementation and evaluation of flipped classroom in Chinese language course. Proceedings of Multidisciplinary Academic Conference, 1-8.

Compton, J.D. (2016). Flipped Learning with Turkish Students: Issues of Dissonance to Possible Harmonization. The Global e-learning Journal, 5(2).

Elfatah, Mervat Abd \& Ahmed, A.S. (2016). The Effect of a Flipping Classroom on Writing Skill in English as a Foreign Language and Students' Attitude towards Flipping. US-China Foreign Language. 14(2), 98-114. https://doi.org/10.17265/1539-080/2016.02.003

Engin, M. (2014). Extending the flipped classroom model: Developing second language writing skills through student-created digital videos. Journal of the Scholarship of Teaching and Learning, 14(5), 12-26. https://doi.org/10.14434/josotlv14i5.12829

Evseeva, A., \& Solozhenko, A. (2015). Use of Flipped Classroom Technology in Language Learning. Social and Behavioral Sciences, 206, 205-209. https://doi.org/10.1016/j.sbspro.2015.10.006

Hao, Y. (2016). Middle school students' flipped learning readiness in foreign language classrooms: Exploring its relationship with personal characteristics and individual circumstances. Computers in Human Behavior, 59, 
295-303. https://doi.org/10.1016/j.chb.2016.01.031

Hsieh, J., Huang Y. M., \& Wu, W.C. (2017). Technological acceptance of LINE in flipped EFL oral training. Computers in Human Behavior, 70, 178-190.

Hsieh, J., Wu, W.C., \& Marek, M. W. (2017. Using the flipped classroom to enhance EFL learning. Computer Assisted Language Learning, 30(1-2), 1-21. https://doi.org/0.1080/09588221.2015.1111910

Hung, H. T. (2017). Clickers in the flipped classroom: bring your own device (BYOD) to promote student learning. Interactive Learning Environments, 25(8), 983-995. https://doi.org/10.1080/10494820.2016.1240090

Hung, H-T. (2015). Flipping the classroom for English language learners to foster active learning. Computer Assisted Language Learning, 28(1), 81-96. https://doi.org/10.1080/09588221.2014.967701

Kang, N. (2015). The Comparison between Regular and Flipped Classrooms for EFL Korean Adult Learners. Multimedia Assisted Language Learning, 18(3), 41-72.

Karimi, M., \& Hamzavi, R. (2017). The Effect of Flipped Model of Instruction on EFL Learners' Reading Comprehension: Learners' Attitudes in Focus. Advances in Language and Literary Studies, 8(1), 95-103. https://doi.org/10.7575/aiac.alls.v.8n.1p.95

Leis, A., Cooke, S., \& Tohei, A. (2015). The effects of flipped classrooms on English Composition writing in an EFL environment. International Journal of Computer Assisted Language Learning and Teaching, 5(4), 37-51. https://doi.org/10.4018/IJCALLT.2015100103

McKeown, J. (2016). From "sage on the stage to guide on the side": a case study of a transition to flipped English language learning in a higher education setting in Turkey. International Association of Research in Foreign Language Education and Applied Linguistics ELT Research Journal 2016, 5(2), 145-154.

Moranski, K., \& Henery, A. (2017). Helping Learners to Orient to the Inverted or Flipped Language Classroom: Mediation via Informational Video. Foreign Language Annals, 50(2), 285-305. https://doi.org/10.1111/flan.12262

Moranski, Kara \& Frederic Kim. (2016). 'Flipping' Lessons in a Multi-Section Spanish Course: Implications for Assigning Explicit Grammar Instruction Outside of the Classroom. The Modern Language Journal, 100(4), 830-852. https://doi.org/10.1111/modl.12366

Soliman, N.A. (2016). Teaching English for Academic Purposes via the Flipped Learning Approach. Procedia Social and Behavioral Sciences, 232(2016), 122-129. https://doi.org/10.1016/j.sbspro.2016.10.036

Soltanpour, F., \& Valizadeh, M. (2018). A Flipped Writing Classroom: Effects on EFL Learners' Argumentative Essays. Advances in Language and Literary Studies, 9(1), 5-13. https://doi.org/10.7575/aiac.alls.v.9n.1p.5

Thaichay, T., \& Sitthitikul, P. (2016). Effects of the Flipped Classroom Instruction on Language Accuracy and Learning Environment: A Case Study of Thai EFL Upper-Secondary School Students. Rangsit Journal of Educational Studies, 3(2), 35-64.

Tseng, M. F., Lin, C.H., \& Chen, H. (2018). An immersive flipped classroom for learning Mandarin Chinese: design, implementation, and outcomes. Computer Assisted Language Learning. https://doi.org/10.1080/09588221.2018.1440603

Wang, J., An, N., \& Wright, C. (2018). Enhancing beginner learners' oral proficiency in a flipped Chinese foreign language classroom. Computer Assisted Language Learning. https://doi.org/10.1080/09588221.2017.1417872

Wu, W.-C. V., Chen Hsieh, J. S., \& Yang J. C. (2017). Creating an Online Learning Community in a Flipped Classroom to Enhance EFL Learners' Oral Proficiency. Educational Technology \& Society, 20(2), 142-157.

Yu, Z., \& Wang, G. (2016). Academic Achievements and Satisfaction of the Clicker-Aided Flipped Business English Writing Class. Educational Technology \& Society, 19(2), 298-312. 
Appendix B. Lists of the Reviewed Thesis about the Use of Flipped Classrooms in Foreign Language Education

\begin{tabular}{llllll}
\hline & & \multicolumn{1}{c}{ AUTHOR } & YEAR & $\begin{array}{c}\text { THESIS } \\
\text { TYPE }\end{array}$ & UNIVERSITY \\
\hline THESIS & 1. & Carranza, A. & 2016 & Doctoral Thesis & California State University \\
FROM & 2. & Farah, M. & 2014 & Master's Thesis & The British University in Dubai \\
ABROAD & 4. & Mehring, J. G. & 2014 & Dectoral Thesis & Pepperdine University \\
& 5. & Prefume, Y. E. & 2015 & Doctoral Thesis & Baylor University \\
& 6. & Tom, K. & 2015 & Master's Thesis & San Diego State University \\
& 7. & Rubi, J. V. & 2017 & Doctoral Thesis & University of Iowa \\
& 8. & Wang, T. & 2014 & Doctoral Thesis & Washington State University \\
& 9. & Warden, A. & 2016 & Master's Thesis & University of Chichester \\
\hline THESIS & 10. & Boyraz, S. & 2014 & Master's Thesis & Afyon Kocatepe University \\
FROM & 11. & Ceylaner, S. & 2016 & Master's Thesis & Mersin University \\
TURKEY & 12. & Caliskan, N. & 2016 & Master's Thesis & Cag University \\
& 13. & Cibik, B. & 2017 & Master's Thesis & Mugla Stki Kocman University \\
& 14. & Edis, S. & 2017 & Master's Thesis & Gazi University \\
& 15. & Ekmekci, E. & 2014 & Doctoral Thesis & Gazi University \\
& 16. & Gok, D. & 2016 & Master's Thesis & Suleyman Demirel Univ. \\
& 17. & Koroglu, Z. C. & 2015 & Doctoral Thesis & Gazi University \\
& 18. & Ozturk, S.Y. & 2018 & Master's Thesis & Gazi University \\
& 19. & Saglam, D. & 2016 & Master's Thesis & Bulent Ecevit University \\
& 20. & Senel, N. & 2017 & Master's Thesis & Anadolu University \\
& 21. & Umutlu, D. & 2016 & Master's Thesis & Bogazici University \\
\hline
\end{tabular}

